\title{
The need for endodontic treatment and systemic characteristics of hematopoietic stem cell transplantation patients
}

Julia Mourão BRAGA-DINIZ(a) Caroline Christine SANTA-ROSA(a) Renata de Castro MARTINS ${ }^{(b)}$ Maria Elisa Souza e SILVA(a) Leda Quercia VIEIRA ${ }^{(c)}$ Antônio Paulino RIBEIRO SOBRINHO(a)

(a) Universidade Federal de Minas Gerais - UFMG, School of Dentistry, Departament of Operative Dentistry, Belo Horizonte, MG, Brazil.

(b) Universidade Federal de Minas Gerais - UFMG, School of Dentistry, Department of Social and Preventive Dentistry, Belo Horizonte, MG, Brazil.

(c) Universidade Federal de Minas Gerais - UFMG, Institute of Biological Sciences, Department of Biochemistry and Immunology, Belo Horizonte, MG, Brazil.

Declaration of Interests: The authors certify that they have no commercial or associative interest that represents a conflict of interest in connection with the manuscript.

Corresponding Author:

Antônio Paulino Ribeiro Sobrinho

E-mail: sobrinho.bhz@gmail.com

https://doi.org/10.1590/1807-3107BOR-2017.vol31.0050

Submitted: Feb 14, 2017

Accepted for publication: Apr 27, 2017

Last revision: May 18, 2017
Abstract: The aim of this study is to investigate the relationship between the epidemiological and clinical profiles of patients before and after hematopoietic stem cell transplantation (HSCT) and the need for endodontic treatment. The subjects included 188 individuals enrolled in the dental care program for transplanted patients of the School of Dentistry, Federal University of Minas Gerais (Faculdade de Odontologia da Universidade Federal de Minas Gerais, FO-UFMG) from March 2011 through March 2016. The patients were subjected to an HSCT conditioning dental regimen based on a thorough clinical and radiographic evaluation. Intraoral periapical and bite-wing X-rays were obtained, and after evaluation, specific dental treatment was planned and performed. The following demographic and clinical data were collected from the patients' medical records: age, gender, transplantation stage, primary disease, transplant type, medication used, complete blood count at the time of visit, and need for endodontic treatment. The Kolmogorov-Smirnov and the chi-square tests were used. Leukemia (31.3\%) and multiple myeloma $(17.9 \%)$ were the most prevalent primary diseases. Most patients were subjected to allogeneic-related transplantation (83.6\%). Most patients exhibited platelet counts and hemoglobin concentrations below the reference values in the pre-transplantation stage, while the neutrophil and platelet counts and the hemoglobin levels were within the reference ranges in the post-transplantation stage. The proportions of individuals requiring endodontic treatment were similar between the pre- and post-transplantation groups: $24.3 \%$ and $24.7 \%$, respectively. The systemic conditions of the patients referred for dental treatment were compromised.

Keywords: Immunosuppression; Hematopoietic stem cell transplantation; Endodontics.

\section{Introduction}

Dental caries and periapical disease are the two most common pathological conditions that affect the mouth; both might be associated with severe systemic complications. ${ }^{1}$ Bacterial contamination of the dental pulp might cause its destruction and the consequent development of periapical lesions, ${ }^{2}$ which represent a potential site for dissemination 
of infection. More than $80 \%$ of patients subjected to hematopoietic stem cell transplantation (HSCT) develop at least one episode of infection, and $40 \%$ of deaths are due to complications from infection alone or following graft rejection. Approximately $55 \%$ of post-transplantation infections are caused by bacteria or viruses, and $15 \%$ to $30 \%$ are caused by fungi. ${ }^{3}$ The occurrence of infection depends on the patient's immune response and degree of immunosuppression. ${ }^{4}$

HSCT is widely performed for the treatment of malignant blood disorders, including acute and chronic leukemia, aplastic anemia, myelodysplastic syndromes, severe combined immunodeficiency, lymphoma and some solid tumors, such as breast cancer. The prevalence of oral complications among autologous and allogeneic HSCT recipients is high, the most common being mucositis, xerostomia, palate disorders, graft versus host disease (GVHD) and infection. Complications are associated with a substantial increase in morbidity, with significant impairment of the patient's quality of life even many years after transplantation. ${ }^{5}$ Complications derived from root canal infections might occur at any stage of the transplantation process and can cause significant problems, such as systemic infection or other disorders, which increase the cost and mortality rate associated with transplantation. ${ }^{6}$ While in autologous HSCT transplantation most of these problems become minimized six months after the procedure; patients subjected to allogeneic transplantation might subsequently develop GVHD-related complications. ${ }^{5}$

Prevention of systemic complications demands achieving stabilization or elimination of oral infection before the onset of transplantation or myelosuppressive therapy. ${ }^{6}$ Additionally, the possible late consequences of total body irradiation and highdose chemotherapy in immunosuppressed patients are a cause of much concern. ${ }^{7}$

Global care of patients subjected to HSCT also includes routine dental assessments within a multi-professional context. The aim of the present study was to investigate the relationship between the epidemiological and clinical profiles of patients before and after HSCT and the need for endodontic treatment.

\section{Methodology}

\section{Patients}

The study population consisted of individuals enrolled in the dental care program for transplanted patients of the School of Dentistry, Federal University of Minas Gerais (Faculdade de Odontologia da Universidade Federal de Minas Gerais, FO-UFMG). These patients were referred by the HSCT service, Clinical Hospital, UFMG (Hospital de Clínicas, HC-UFMG), from March 2011 through March 2016. Patients whose medical records could not be retrieved were excluded from the study. The patients were subjected to an HSCT conditioning dental regimen based on a specific protocol applied at the HSCT Unit, HC-UFMG. The conditioning dental regimen consisted of a thorough clinical and radiographic evaluation of the patient. Intraoral periapical and bite-wing X-rays and panoramic radiographs were obtained. The criteria adopted to determine the need for endodontic treatment were based on clinical and radiographic analyses, along with pulp vitality tests. After further evaluation, specific dental treatment was planned and performed while considering the time available before transplantation and the patient's systemic condition. The patients also received dental care after transplantation to maintain their oral health.

\section{Personal data and clinical characteristics}

Demographic and clinical data were collected from the patients' medical records and included the following: age, gender, transplantation stage, primary disease, transplant type, medication in use, complete blood count at the time of visit, need for endodontic treatment and number of endodontic treatments performed during the conditioning dental regimen. Missing or incomplete data were registered as "Missing/omitted data".

\section{Statistical analysis}

In the descriptive analysis, the quantitative variables are expressed as means and standard deviations. The Kolmogorov-Smirnov test was used to investigate whether the data had a normal distribution, and the chi-square test was employed to establish whether there were statistically significant associations between 
variables. Statistical significance was defined as a p-value of 0.05 or less.

\section{Ethics issues}

The present study complied with the ethics requirements described in Health Ministry Resolution no. 196/96 and was approved by the research ethics committee of UFMG (CAAE: 54829414.7.0000.5149/ ruling:1.569.493; CAAAE: Certificado de Apresentação para Apreciação Ética/Certificate of Presentation for Ethical Appraisal).

\section{Results}

\section{Patients' characteristics}

A total of 188 individuals enrolled in the Program of Dental Care for Transplanted Patients, FO-UFMG, from March 2011 through March 2016, were included in the study; $60.6 \%$ were male, and $39.4 \%$ were female. The participants' ages varied from 06 to 69 years old. A total of 103 patients were in the pre-transplantation stage, and 85 were in the post-transplantation stage. Most were allogeneic-related transplants (83.6\%), while allogeneic-unrelated transplants corresponded to $9.6 \%$ and autologous transplants to $6.8 \%$ (Table 1 ). There was no statistically significant association between gender and donor type $(p=0.57)$. The median time from diagnosis to transplantation was 12 months.

Table 1. Description of the patients' characteristics.

\begin{tabular}{lcc}
\hline Variable & Frequency & $\%$ \\
\hline Patients & & \\
$\quad$ Before HSCT & 103 & 54.8 \\
After HSCT & 85 & 45.2 \\
Total & 188 & 100 \\
Gender & & \\
Male & 114 & 60.6 \\
Female & 74 & 39.4 \\
Total & 188 & 100 \\
Transplant type & & \\
Allogeneic related & 61 & 83.6 \\
Allogeneic unrelated & 7 & 9.6 \\
Autologous & 5 & 6.8 \\
Total & 73 & 100 \\
Missing & 12 & - \\
\hline
\end{tabular}

HSCT: hematopoietic stem cell transplantation.

\section{Need for endodontic treatment}

The frequencies of endodontic treatment were $24.3 \%$ and $24.7 \%$ before and after HSCT, respectively, corresponding to $23.2 \%$ of the targeted sample. No statistically significant difference was observed between the groups $(p>0.05)$. Most patients required endodontic treatment for more than one tooth.

\section{Systemic disease that led to HSCT}

Leukemia corresponded to $31.3 \%$ of the cases and was the predominant condition among individuals enrolled in the Program of Dental Care for Transplanted Patients, FO-UFMG, both before and after HSCT. Acute myeloid leukemia (AML) was exhibited by $15.7 \%$ of the sample, chronic myeloid leukemia (CML) by $12.4 \%$, acute lymphocytic leukemia (ALL) by $2.7 \%$ and chronic lymphocytic leukemia (CLL) by $0.5 \%$. Approximately $15.1 \%$ of the patients had bone marrow aplasia, and $17.9 \%$ had multiple myeloma (Table 2).

Leukemia was also the main primary disease among transplanted individuals enrolled in the Program of Dental Care for Transplanted Patients, FO-UFMG, $44.1 \%$, with $22.6 \%$ cases of AML, $16.7 \%$ cases of CML, and $4.8 \%$ cases of ALL. Approximately $22.6 \%$ of the patients had bone marrow aplasia and $8.3 \%$ had myelodysplastic syndromes as the primary disorder.

Table 2. Percentages of systemic diseases exhibited by individuals enrolled in the Program of Dental Care for Transplanted Patients, FO-UFMG.

\begin{tabular}{lccc}
\hline \multirow{2}{*}{ Primary disease } & \multicolumn{3}{c}{ Patient } \\
\cline { 2 - 4 } & Global & Before HSCT & After HSCT \\
\hline Leukemia & $31.3 \%$ & $20.8 \%$ & $44.1 \%$ \\
CML & $12.4 \%$ & $8.9 \%$ & $16.7 \%$ \\
AML & $15.7 \%$ & $9.9 \%$ & $22.6 \%$ \\
ALL & $2.7 \%$ & $1.0 \%$ & $4.8 \%$ \\
CLL & $0.5 \%$ & $1.0 \%$ & $0.0 \%$ \\
Multiple myeloma & $17.9 \%$ & $27.7 \%$ & $6.0 \%$ \\
Myelodysplastic syndrome & $4.9 \%$ & $2.0 \%$ & $8.3 \%$ \\
Bone marrow aplasia & $15.1 \%$ & $8.9 \%$ & $22.6 \%$ \\
Non-Hodgkin's lymphoma & $4.3 \%$ & $5.0 \%$ & $3.6 \%$ \\
Hodgkin's lymphoma & $4.3 \%$ & $5.9 \%$ & $2.4 \%$ \\
Other & $22.2 \%$ & $29.7 \%$ & $13.1 \%$ \\
Total & $100 \%$ & $100 \%$ & $100 \%$ \\
\hline HSCT: hematopoietic stem cell transplantation; CML: chronic \\
myeloid leukemia; AML: Acute myeloid leukemia; ALL: acute \\
lymphocytic leukemia ; CLL: chronic lymphocytic leukemia.
\end{tabular}




\section{Hematologic analysis before and after HSCT}

In most patients (56.5\%), the neutrophil count was within the reference range before HSCT. However, the platelet count and hemoglobin concentration were below the reference values in $54.3 \%$ and $63 \%$ of the sample, respectively. There were no statistically significant relationships between gender $(p>0.05)$ and neutrophil and platelet counts and hemoglobin concentration.

In most individuals in the Program of Dental Care for Transplanted Patients (FO-UFMG), after HSCT, the neutrophil and platelet counts and hemoglobin concentration were within the reference ranges, i.e., $64.4 \%, 70.4 \%$ and $76.1 \%$ of the sample, respectively. There were no statistically significant relationships between gender and neutrophil and platelet counts and hemoglobin concentration $(p>0.05)$ (Figure 1).

\section{Prescribed medications and percentages of patients using medication before and after HSCT}

Most of the analyzed patients (75.5\%) used some medication.

After HSCT, $52.9 \%$ of the patients used immunosuppressive agents, and $51.8 \%$ of them used antibiotics, with cyclosporine and Bactrim ${ }^{\circledR}$ used as the first choices, respectively.

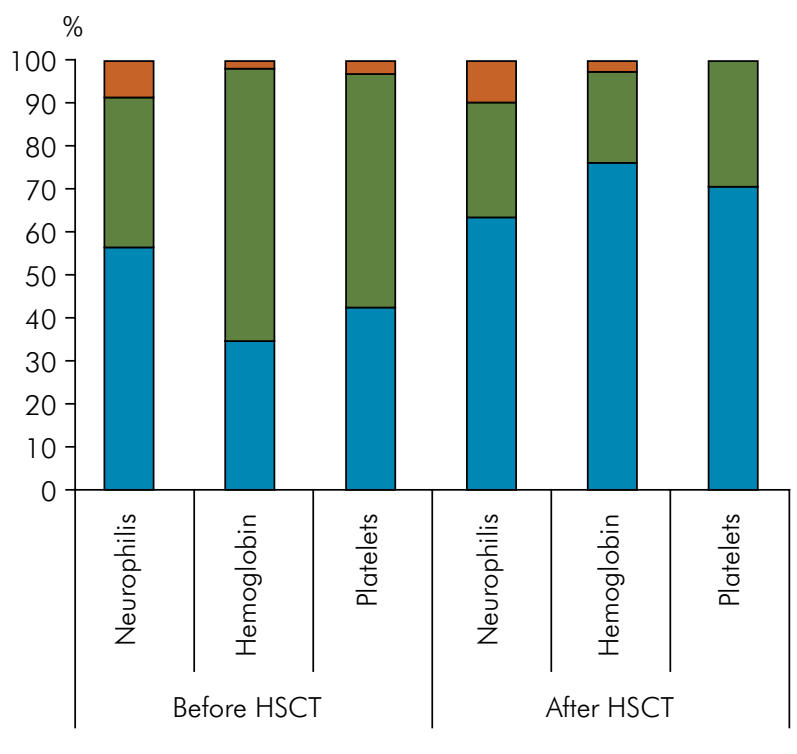

Figure 1. Complete blood results of individuals enrolled in the Program of Dental Care for Transplanted Patients, FO-UFMG.
A total of $23.3 \%$ of the patients in the pretransplantation stage used anticancer drugs, and 13.6\% used bisphosphonate. Antihypertensive drugs were continuously used by $20.4 \%$ and $25.9 \%$ of the patients before and after HSCT, respectively. Steroids were used by $22.3 \%$ and $18.8 \%$ of the pre- and post-transplantation patients, respectively (Table 3 ).

Table 3. Percentages of medications used by individuals enrolled in the Program of Dental Care for Transplanted Patients, FO-UFMG.

\begin{tabular}{|c|c|c|c|}
\hline \multirow[b]{2}{*}{ Medication } & \multicolumn{3}{|c|}{ Patients (\%) } \\
\hline & Global & $\begin{array}{l}\text { Before } \\
\text { HSCT }\end{array}$ & $\begin{array}{l}\text { After } \\
\text { HSCT }\end{array}$ \\
\hline In use & 75.5 & 75.7 & 75.3 \\
\hline Immunosuppressant & 23.9 & 0.0 & 52.9 \\
\hline Tacrolimus & 5.3 & 0.0 & 11.8 \\
\hline Cyclosporine & 18.6 & 0.0 & 41.2 \\
\hline Steroids & 20.7 & 22.3 & 18.8 \\
\hline Opioid analgesics & 4.8 & 6.8 & 2.4 \\
\hline Antibiotics & 41.0 & 32 & 51.8 \\
\hline Bactrim ${ }^{\circledR}$ & 36.8 & 27.2 & 48.2 \\
\hline Penicillin & 4.8 & 3.9 & 5.9 \\
\hline Clindamycin & 0.5 & 0.0 & 1.2 \\
\hline Cephalosporin & 0.5 & 1.0 & 0.0 \\
\hline Tetracycline & 0.5 & 1.0 & 0.0 \\
\hline Norfloxacin & 2.0 & 1.0 & 3.5 \\
\hline Antifungal & 1.0 & 1.9 & 0.0 \\
\hline Acyclovir & 1.0 & 1.9 & 0.0 \\
\hline Antihypertensives & 22.9 & 20.4 & 25.9 \\
\hline Nifedipine/Amlodipine & 8.5 & 1.9 & 16.5 \\
\hline Atenolol/Propranolol/Metoprolol & 5.3 & 5.8 & 4.7 \\
\hline Losartan & 6.4 & 7.8 & 4.7 \\
\hline Captopril/Enalapril & 6.4 & 5.8 & 7.1 \\
\hline Antineoplastic & 13.8 & 23.3 & 2.4 \\
\hline Cyclophosphamide & 7.0 & 11.7 & 1.2 \\
\hline Hydroxyurea & 2.0 & 2.9 & 1.2 \\
\hline Dasatinib/Sprycel ${ }^{\circledR}$ & 2.0 & 3.9 & 0.0 \\
\hline Imatinib & 1.5 & 2.9 & 0.0 \\
\hline Other & 1.5 & 3.9 & 0.0 \\
\hline Bisphosphonate & 9.6 & 13.6 & 4.7 \\
\hline Diuretics & 4.8 & 6.8 & 2.4 \\
\hline Hydrochlorothiazide & 2.0 & 3.9 & 0.0 \\
\hline Furosemide & 1.5 & 2.9 & 0.0 \\
\hline Spironolactone & 1.5 & 1.0 & 2.4 \\
\hline Antacid & 35.7 & 22.3 & 51.8 \\
\hline Hormone supplements & 5.3 & 1.0 & 10.6 \\
\hline Vitamin complex & 3.7 & 4.9 & 2.4 \\
\hline Anticoagulant & 9.6 & 16.5 & 1.2 \\
\hline Antidepressant & 7.0 & 7.8 & 5.9 \\
\hline
\end{tabular}

HSCT: hematopoietic stem cell transplantation. 


\section{Discussion}

Apical periodontitis is an inflammatory disease that affects the tissues surrounding the apical portion of the dental root and is primarily caused by microorganisms infecting the root canal. It represents a potential site for dissemination of infection. ${ }^{2}$ Root canal infections among autologous and allogeneic HSCT recipients can be associated with a substantial increase in morbidity, with significant impairment of the patient's quality of life. ${ }^{5}$ This study evaluated the need for endodontic treatment in patients before and after HSCT by analyzing their systemic data and correlating these data with the risk of persistent endodontic infections among HSCT recipients.

Autologous HSCT is used for the treatment of malignant conditions, such as multiple myeloma and Hodgkin's and non-Hodgkin's lymphoma. Allogeneic transplantation is often the first-choice treatment for several malignant blood diseases, such as AML, CML, ALL, CLL and severe aplastic anemia. In the present study, almost all of the participants with the abovementioned conditions were subjected to allogeneic HSCT (83.6\%). In addition, a retrospective cohort study conducted in Brazil found that most (72\%) among 731 patients subjected to HSCT for the treatment of AML received allogeneic transplants. ${ }^{8}$ However, these findings disagree with other reports in the literature. One study performed in Spain found that among 228 patients subjected to HSCT, $55.7 \%$ received autologous transplants and $44.3 \%$ received allogeneic transplants. 9 Another study analyzed data from 1516 transplant centers in 75 countries and demonstrated that the largest proportion of patients received autologous transplants $(58 \%))^{10}$ The mortality rate is lower for autologous compared to allogeneic transplantation, with the 5-year mortality associated with allogeneic transplantation varying from $24 \%$ to $34 \% .11,12$

Interestingly, most of the patients analyzed in the present study were male. This finding disagrees with findings corresponding to individuals infected with human immunodeficiency virus (HIV) and subjected to highly active antiretroviral therapy (HAART) and patients with aplastic anemia, most of whom are female (57.2\% and 56.5\%, respectively). ${ }^{13,14}$ The median time from diagnosis to transplantation was rather long, approximately 12 months. In one retrospective study conducted in Porto Alegre, Rio Grande do Sul (RS), Brazil, in 2013, ${ }^{15}$ the time to transplantation was less than 12 months for the majority (62.9\%) of patients ( $n=278$ ) subjected to allogeneic HSCT.

Leukemia was the main reason for the analyzed population to be included in the study groups, i.e., before or after HSCT. In other studies, leukemia was also the main primary malignant disease that led to transplantation. ${ }^{9,10,15,16}$ The fact that only $6 \%$ of the 84 patients subjected to transplantation had multiple myeloma is noteworthy. The reason for such a low prevalence of this condition is that the odds of a cure are very low, and patients exhibit poor survival rates. ${ }^{17,18}$ In contrast, another study reported a larger proportion of patients with multiple myeloma (20.15\%) among 137 individuals subjected to HSCT. ${ }^{19}$

As a rule, patients subjected to HSCT exhibit pancytopenia before and immediately after transplantation and remain in a state of neutropenia for approximately 6 to 12 months after the procedure. Root canal infections might have serious consequences during this neutropenic period and can eventually compromise graft success..$^{20}$ The high risk of bacterial infection after HSCT is due to severe neutropenia and the damage to the body barriers caused by the conditioning regime. ${ }^{21}$ In our study, only $56.5 \%$ of the patients in the pre-transplantation stage exhibited neutrophil counts within the reference range; this proportion was lower compared to the transplanted patients (63.4\%). In addition, most of the patients in the pre-transplantation stage had platelet counts and hemoglobin concentrations below the reference values.

HSCT induces a state of immunosuppression, made even worse by various medications, as shown in the present study. Approximately $20.74 \%$ of the patients used steroids, which have strong effects on the distribution and function of neutrophils, monocytes and lymphocytes. In cancer patients, steroids seldom are the only class of immunosuppressive drugs prescribed; therefore, it is difficult to assess their impact on the immune system. The risk of infection is associated with the dose and duration of treatment, the degree of neutropenia and the use of immunosuppressive agents (https://www.nccn. org/professional/physician_gls/PDF/infections.pdf). 
Prophylactic antibiotic therapy is commonly indicated after HSCT. In our study, $51.8 \%$ of the transplanted patients used antibiotics. The NCCN (National Comprehensive Cancer Network) guidelines classify cancer patients as at low, medium or high risk for infection based on factors such as primary disease, duration of neutropenia, first exposure to chemotherapy, degree of disease activity and intensity of immunosuppressive therapy. Antimicrobial prophylaxis should be considered for individuals at medium or high risk of infection. Fluoroquinolones (Bactrim ${ }^{\circledR}$ ) are the antibiotics indicated to patients with chemotherapy-induced neutropenia and significantly reduce the incidence of infection with Gram-negative bacteria. Antibiotic prophylaxis against pneumococcal infection is indicated for patients with low immunoglobulin (Ig)G levels and chronic GVHD. Antibiotic prophylaxis must also be prescribed to patients vaccinated against pneumococcal disease and should last at least one year following HSCT. ${ }^{22}$

HSCT makes patients more susceptible to infection, as the oral cavity is a relevant source of pathogens likely to cause systemic disorders in this population. ${ }^{5}$ It is believed that infections of oral origin occur in approximately $80 \%$ of cases. ${ }^{11}$ Pulpal and periradicular diseases usually result from direct or indirect involvement of microorganisms present in the oral cavity. ${ }^{23,24,25}$ Changes might occur in the oral microbiota before and after chemotherapy. ${ }^{26}$ One cohort study found significant increases of oral colonization by opportunistic pathogens, such as Enterococcus faecalis and Candida spp., among individuals subjected to allogeneic transplantation. ${ }^{27}$ Medically relevant microorganisms, such as Pseudomonas aeruginosa, Staphylococcus aureus, Escherichia coli, Streptococcus sanguinis and Prevotella intermedia ${ }^{28,29,30,31}$ have been detected in infected root canal systems, which highlights the need for endodontic treatment, especially in the case of immunosuppressed patients, such as the patients analyzed in the present study.

Analyses of the need for endodontic treatment of a given population are difficult to find in the international literature, ${ }^{13,14}$ the same applies to cases of patients subjected to or to being subjected to HSCT. In the present study, $23.2 \%$ of the patients required endodontic intervention. This rate seems quite high when compared to those found for Brazil as a whole within the context of the Health Ministry "SB Brasil" (Oral Health, Saúde Bucal - SB) program, which were $6.2 \%$ and $4.3 \%$ for the age ranges 15 to 19 and 35 to 44 years old, respectively. Rates varying from $1.8 \%$ to $13 \%$ were published for adolescents in Lithuania and Manhattan (USA), respectively. ${ }^{32,33}$ The rates found in the present study are also somewhat higher than those obtained for individuals with sickle cell anemia $(10.2 \%)^{14}$ and HIV-seropositivity under HAART $(14 \%){ }_{1}^{13}$ which is fully consistent with the severe degree of immunosuppression exhibited by patients subjected to HSCT. Although HSCT is crucial for the improvement and survival of patients, infection after transplantation is a relevant cause of morbidity and mortality. Countless factors determine the success or failure of this type of systemic intervention.

\section{Conclusion}

The systemic conditions of the patients referred for dental treatment were compromised, especially in the pre-transplantation stage, and were associated with a high prevalence of the need for endodontic treatment. In the last instance, these findings show that when untreated, root canal infections will unequivocally compromise attempts at ensuring global health for this population of patients, along with HSCT itself. Finally, the present study incisively seeks to bring the need for consistent interdisciplinary analysis into debate in the various fields of knowledge to attain increasingly more satisfactory and substantial results in the attempt at ensuring global health to patients requiring stem cell transplantation.

\section{Acknowledgements}

This work was supported by Fundação de Amparo à Pesquisa do Estado de Minas Gerais (FAPEMIG), Coordenação de Aperfeiçoamento de Pessoal de Nível Superior (CAPES), and Conselho Nacional de Desenvolvimento Científico e Tecnológico (CNPq). The authors wish to thank the postgraduate program at the School of Dentistry of UFMG. APRS and LQV are CNPq fellows. The authors declare no potential conflicts of interest. 


\section{References}

1. Overholser CD, Peterson DE, Williams LT, Schimpff SC. Periodontal infection in patients with acute nonlymphocyte leukemia. Prevalence of acute exacerbations. Arch Intern Med. 1982;142(3):551-4. https://doi.org/10.1001/archinte.1982.00340160131025

2. Takahashi K. Microbiological, pathological, inflammatory, immunological and molecular biological aspects of periradicular disease. Int Endod J. 1998;31(5):311-25. https://doi.org/10.1046/j.1365-2591.1998.00171.x

3. Eun SC. Composite tissue allotransplantation immunology. Arch Plast Surg. 2013;40(2):141-53. https://doi.org/10.5999/aps.2013.40.2.141

4. Nappalli D, Lingappa A. Oral manifestations in transplant patients. Dent Res J (Isfahan). 2015;12(3):199-208.

5. Haverman TM, Raber-Durlacher JE, Rademacher WM, Vokurka S, Epstein JB, Huisman C et al. Oral complications in hematopoietic stem cell recipients: the role of inflammation. Mediators Inflamm. 2014;2014:378281:1-18 https://doi.org/10.1155/2014/378281

6. Forman SJ, Blume KG, Thomas ED. Hematopoietic cell transplantation. Oxford: Blackwell Science; 1999.

7. Curtis RE, Rowlings PA, Deeg HJ, Shriner DA, Socié G, Travis LB et al. Solid cancers after bone marrow transplantation. N Engl J Med. 1997;336(13):897-904. https://doi.org/10.1056/NEJM199703273361301

8. Lamego RM, Clementino NCD, Costa ALB, Oliveira MJM, Bittencourt $\mathrm{H}$. Transplante alogênico de células-tronco hematopoéticas em leucemias agudas: a experiência de dez anos do Hospital das Clínicas da UFMG. Rev Bras Hematol Hemoter. 2010;32(2):108-15. https://doi.org/10.1590/S1516-84842010005000040

9. Corcía Palomo Y, Knight Asorey T, Espigado I, Martín Villén L, Garnacho Montero J. Mortality of oncohematological patients undergoing hematopoietic stem cell transplantation admitted to the intensive care unit. Transplant Proc. 2015;47(9):2665-6. https://doi.org/10.1016/i.transproceed.2015.09.033

10. Gratwohl A, Pasquini MC, Aljurf M, Atsuta Y, Baldomero $\mathrm{H}$, Foeken $\mathrm{L}$ et al. One million haemopoietic stem-cell transplants: a retrospective observational study. Lancet Haematol. 2015;2(3):e91-100. https://doi.org/10.1016/S2352-3026(15)00028-9

11. Greinix HT, Nachbaur D, Krieger O, Eibl M, Knöbl P, Kalhs $\mathrm{P}$ et al. Factors affecting long-term outcome after allogeneic haematopoietic stem cell transplantation for acute myelogenous leukaemia: a retrospective study of 172 adult patients reported to the Austrian Stem Cell Transplantation Registry. Br J Haematol. 2002;117(4):914-23. https://doi.org/10.1046/j.1365-2141.2002.03532.x
12. Doney K, Hägglund H, Leisenring W, Chauncey T, Appelbaum FR, Storb R. Predictive factors for outcome of allogeneic hematopoietic cell transplantation for adult acute lymphoblastic leukemia. Biol Blood Marrow Transplant. 2003;9(7):472-81. https://doi.org/10.1016/S1083-8791(03)00149-6

13. Brito LC, Rosa MA, Lopes VS, Ferreira EF, Vieira LQ, Ribeiro Sobrinho AP. Brazilian HIV-infected population: assessment of the needs of endodontic treatment in the post-highly active antiretroviral therapy era. J Endod. 2009;35(9):1178-81. https://doi.org/10.1016/i.joen.2009.05.004

14. Ferreira SB, Tavares WL, Rosa MA, Brito LC, Vieira LQ, Martelli $\mathrm{H}$ et al. Sickle cell anemia in Brazil: personal, medical and endodontic patterns. Braz Oral Res. 2016;30(1):e60. https://doi.org/10.1590/1807-3107BOR-2016.vol30.0060

15. Pitombeira BS, Paz A, Pezzi A, Amorin B, Valim V, Laureano A et al. Validation of the EBMT risk score for south brazilian patients submitted to allogeneic hematopoietic stem cell transplantation. Bone Marrow Res. 2013;2013:565824:1-7. https://doi.org/10.1155/2013/565824

16. Gratwohl A, Baldomero H, Aljurf M, Pasquini MC, Bouzas LF, Yoshimi $A$ et al. Hematopoietic stem cell transplantation: a global perspective. Jama. 2010;303(16):1617-24 . https://doi.org/10.1001/jama.2010.491

17. Kyle RA, Gertz MA, Witzig TE, Lust JA, Lacy MQ, Dispenzieri A, et al. Review of 1027 patients with newly diagnosed multiple myeloma. Mayo Clin Proc. 2003;78(1):21-33. https://doi.org/10.4065/78.1.21

18. Jemal A, Tiwari RC, Murray T, Ghafoor A, Samuels A, Ward E et al. Cancer statistics, 2004. CA Cancer J Clin. 2004;54(1):8-29. https://doi.org/10.3322/canjclin.54.1.8

19. Barba P, Burns LJ, Litzow MR, Juckett MB, Komanduri KV, Lee $S J$ et al. Success of an international learning health care system in hematopoietic cell transplantation: The American Society of Blood and Marrow Transplantation Clinical Case Forum. Biol Blood Marrow Transplant. 2016;22(3):564-70. https://doi.org/10.1016/j.bbmt.2015.12.008

20. Bishay N, Petrikowski CG, Maxymiw WG, Lee L, Wood RE. Optimum dental radiography in bone marrow transplant patients. Oral Surg Oral Med Oral Pathol Oral Radiol Endod. 1999;87(3):375-9. https://doi.org/10.1016/S1079-2104(99)70227-1

21. Sviland L, Pearson AD, Green MA, Baker BD, Eastham EJ, Reid MM, et al. Immunopathology of early graft-versus-host disease: a prospective study of skin, rectum, and peripheral blood in allogeneic and autologous bone marrow transplant recipients. Transplantation. 1991;52(6):1029-36. https://doi.org/10.1097/00007890-199112000-00018 
The need for endodontic treatment and systemic characteristics of hematopoietic stem cell transplantation patients

22. Tomblyn M, Chiller T, Einsele H, Gress R, Sepkowitz K et al. Guidelines for preventing infectious complications among hematopoietic cell transplant recipients: a global perspective. Biol Blood Marrow Transplant. 2009;15(10):1143-238. https://doi.org/10.1016/i.bbmt.2009.06.019

23. Fabricius L, Dahlén G, Holm SE, Möller AJ. Influence of combinations of oral bacteria on periapical tissues of monkeys. Scand J Dent Res. 1982;90(3):200-6.

24. Moller AJ. Microbiological examination of root canals and periapical tissues of human teeth. Methodological studies. Odontol Tidskr. 1966;74(5):Suppl:1-380.

25. Sundqvist GK, Eckerbom MI, Larsson AP, Sjögren UT. Capacity of anaerobic bacteria from necrotic dental pulps to induce purulent infections. Infect Immun. 1979;25(2):685-93.

26. Napeñas JJ, Brennan MT, Coleman S, Kent ML, Noll J, Frenette $G$ et al. Molecular methodology to assess the impact of cancer chemotherapy on the oral bacterial flora: a pilot study. Oral Surg Oral Med Oral Pathol Oral Radiol Endod. 2010;109(4):554-60. https://doi.org/10.1016/i.tripleo.2009.11.015

27. Vokurka S, Skardova J, Hruskova R, Kabatova-Maxova K, Svoboda T, Bystricka E et al. The effect of polyvinylpyrrolidone-sodium hyaluronate gel (Gelclair) on oral microbial colonization and pain control compared with other rinsing solutions in patients with oral mucositis after allogeneic stem cells transplantation. Med Sci Monit. 2011;17(10):CR572-6. https://doi.org/10.12659/MSM.881983
28. Henriques LC, Brito LC, Tavares WL, Teles RP, Vieira LQ, Teles FR et al. Microbial Ecosystem Analysis in Root Canal Infections Refractory to Endodontic Treatment. J Endod. 2016; 42(8):1239-45. https://doi.org/10.1016/i.joen.2016.05.014

29. Brito LC, Teles FR, Teles RP, França EC, Ribeiro-Sobrinho AP, Haffajee AD et al. Use of multiple-displacement amplification and checkerboard DNADNA hybridization to examine the microbiota of endodontic infections. J Clin Microbiol. 2007;45(9):3039-49. https://doi.org/10.1128/JCM.02618-06

30. Tavares WL, Neves de Brito LC, Teles RP, Massara $M L$, Ribeiro Sobrinho AP, Haffajee AD et al. Microbiota of deciduous endodontic infections analysed by MDA and Checkerboard DNA-DNA hybridization. Int Endod J. 2011;44(3):225-35. https://doi.org/10.1111/j.1365-2591.2010.01805.x

31. Siqueira Junior JF, Alves FR, Rocas IN. Pyrosequencing analysis of the apical root canal microbiota. J Endod. 2011;37(11):1499-503. https://doi.org/10.1016/i.joen.2011.08.012

32. Brukiene V, Aleksejuniene J, Balciuniene I. Dental treatment needs in Lithuanian adolescents. Stomatologija. $2005 ; 7(1): 11-5$.

33. Mitchell DA, Ahluwalia KP, Albert DA, Zabos GP, Findley SE, Trinh-Shevrin CB et al. Dental caries experience in northern Manhattan adolescents. J Public Health Dent. 2003;63(3):189-94. https://doi.org/10.1111/j.1752-7325.2003.tb03498.x 